\title{
Trypanoxyuris (Paraoxyuronema) lagothricis (Nematoda: Oxyuridae) in Lagothrix cana (Primates: Atelidae) from Brazil
}

\author{
Trypanoxyuris (Paraoxyuronema) lagothricis (Nematoda: Oxyuridae) \\ em Lagothrix cana (Primates: Atelidae) no Brasil
}

Hudson Alves Pinto ${ }^{1 *}$; Francisco Carlos Ferreira Junior ${ }^{1}$; Vitor Luís Tenório Mati ${ }^{1}$; Alan Lane de Melo ${ }^{1}$

\begin{abstract}
${ }^{1}$ Departamento de Parasitologia, Instituto de Ciências Biológicas, Universidade Federal de Minas Gerais - UFMG, Belo Horizonte, MG, Brasil
\end{abstract}

Received October 16, 2012

Accepted January 21, 2013

\begin{abstract}
During necropsy of a specimen of Lagothrix cana (É. Geoffroy, 1812) (Primates: Atelidae) from the Brazilian Amazon, pinworms were found in the large intestine. The intensity of infection was 64 parasites (17 males and 47 females) and there were no gross pathological changes related to parasitism. After morphological analysis the parasites were identified as Trypanoxyuris (Paraoxyuronema) lagothricis (Buckley, 1931) (Nematoda: Oxyuridae). This is the first record of this oxyurid species in primates in Brazil.
\end{abstract}

Keywords: Nematodes, primates, pinworms.

\begin{abstract}
Resumo
Durante a necropsia de Lagothrix cana (É. Geoffroy, 1812) (Primates: Atelidae) oriundo da Amazônia brasileira, oxiurídeos foram encontrados no intestino grosso. A intensidade de infecção foi de 64 parasitos (17 machos e 47 fêmeas), não havendo alterações patológicas macroscópicas relacionadas ao parasitismo. Após análise morfológica os parasitos foram identificados como Trypanoxyuris (Paraoxyuronema) lagothricis (Buckley, 1931) (Nematoda: Oxyuridae). Este é o primeiro relato desta espécie de oxiurídeo em primatas no Brasil.
\end{abstract}

Palavras-chave: Nematódeos, primatas, oxiurídeos.

The pinworm species of the genus Trypanoxyuris Vevers, 1923 (Nematoda: Oxyuridae) are tiny parasites that inhabit the large intestine of Neotropical non-human primates, although there are a few species of these parasites found in rodents (HUGOT, 1999). These helminths are the causative agents of oxyuriasis in platyrrhines and, similarly what can be observed in other pinworms from primates, Trypanoxyuris spp. present a direct life cycle in which it is verified the migration of ovigerous female worms to the perianal area, where oviposition takes place. After a short period of embryonation, the eggs of the parasite become infective and their ingestion is the primary mechanism of transmission (heteroinfection and external autoinfection); however, larvae of the parasite can hatch still in the anus and perianus of the infected host and migrate ascending to the intestine (retroinfection) (FELT; WHITE, 2005).

\footnotetext{
*Corresponding author: Hudson Alves Pinto

Laboratório de Taxonomia e Biologia de Invertebrados,

Departamento de Parasitologia, Instituto de Ciências Biológicas,

Universidade Federal de Minas Gerais - UFMG,

CP 486, CEP 30123-970, Belo Horizonte, MG, Brasil

e-mail: hudsonalves13@ig.com.br
}

So far, 18 species of Trypanoxyuris are known and have been grouped in four subgenera: Trypanoxyuris (Trypanoxyuris) Vevers, 1923 with eight species occurring mainly in Cebinae, with some of them also found in primates of the families Aotidae, Atelidae and Pitheciidae; Trypanoxyuris (Hapaloxyuris) Inglis \& Cosgrove, 1965 with four species described from Callitrichinae; Trypanoxyuris (Paraoxyuronema) Artigas, 1936 with four species from Atelidae; and Trypanoxyuris (Rodentoxyuris) Quentin \& Tenora, 1974 with two species found in rodents of the family Sciuridae in North America and Europe (HUGOT et al., 1996; HUGOT, 1999).

In Brazil, Trypanoxyuris spp. have been reported in non-human primates since the first quarter of the twentieth century, and six species of these parasites were already confirmed parasitizing 10 species of hosts: (1) Trypanoxyuris (Paraoxyuronema) brachytelesi (Artigas, 1936) described from Brachyteles arachnoides (É. Geoffroy, 1806) (Primates: Atelidae); (2) T. (H.) callithricis (Solomon, 1933) reported in Callithrix (Callithrix) jacchus (Linnaeus, 1758) (Primates: Cebidae); (3) T. (T.) clementinae Hugot, 1985 described from Sapajus apella (Linnaeus, 1758) (Primates: Cebidae); (4) T. (T.) microon (Linstow, 1907) found in Aotus trivirgatus (Humboldt, 1811) 
(Primates: Aotidae); (5) T. (T.) minutus (Schneider, 1866) reported in Alouatta caraya (Humboldt, 1812) (Primates, Atelidae), A. guariba clamitans Cabrera, 1940, Ateles paniscus (Linnaeus, 1758), A. belzebul (Linnaeus, 1758), A. fusca (É. Geoffroy, 1812) and Saimiri sciureus (Linnaeus, 1758) (Primates: Cebidae), and (6) T. (T.) sceleratus (Travassos, 1925) described from S. sciureus (TRAVASSOS, 1925; ARTIGAS, 1936; HUGOT, 1984, 1985; VICENTE et al., 1997; VALENÇA et al., 2000; AMATO et al., 2002; MARTINS et al., 2008; SOUZA et al., 2010). Moreover, unidentified species of Trypanoxyuris were recorded in $A$. caraya and S. sciureus (VICENTE et al., 1992) and eggs of these parasites were found in the feces of Aotus azarai infulatus (Kuhl, 1820) (Primates: Aotidae) and $A$. guariba clamitans (SOUZA JÚNIOR et al., 2008; BARROS MONTEIRO et al., 2009). Despite these previous reports, the amount of species of Trypanoxyuris that occurs in Brazilian primates may be higher than previously recorded considering the richness of primate species in Brazil and their helminths, which have not been comprehensively studied.

In the present study, a young male specimen of Lagothrix cana (É. Geoffroy, 1812), Gray Woolly Monkey, captured in an uncertain locality in the Brazilian Amazon and kept, at first, at the Brazilian Institute of Environment and Renewable Natural Resources (IBAMA), was sent from São Luís, state of Maranhão, northeast region, to a conservation unit in the municipality of Inhaúma, state of Minas Gerais, southeastern Brazil. After a short period in captivity, the animal died and necropsy was performed. A fecal sample from the specimen was processed by the spontaneous sedimentation method and eggs with morphology suggestive of oxyurids were found.

Nematodes were observed in the large intestine, fixed in $10 \%$ formalin and later cleared in lactophenol. They were sexed and mounted in nonpermanent preparation between slide and coverslip and examined by light microscopy. Preparation of en face mounts was performed according to Anderson (1958). Images of the parasites were taken by a Leica microscope and the measures were obtained through the analysis of the images in the Leica Application Suite (EZ LAZ) version 2.0 software, except for the total length of the body, which was measured with a curvimeter after the parasites were drawn with the aid of a camera lucida.

The taxonomic identification was based on morphological criteria preconized by several authors. The generic and subgeneric identifications were performed according to Hugot $(1985,1999)$, and the specific determination was carried out according to Buckley (1931) and Hugot (1985). The measures of 20 specimens (10 males and 10 females) are shown in Table 1; they are presented by the mean followed by standard deviation and range between parentheses. Measures are given in micrometers, except for the length of the body which is given in millimeters. The specimens studied were deposited at the taxonomic collection of the "Laboratório de Taxonomia e Biologia de Invertebrados, Universidade Federal de Minas Gerais” (DPIC).

\section{Taxonomic Summary}

Trypanoxyuris (Paraoxyuronema) lagothricis (Buckley, 1931) Hugot et al., 1999 (Figure 1, Table 1).

(Syn.: Enterobius lagothricis Buckley, 1931, Trypanoxyuris (Trypanoxyuris) lagothricis (Buckley, 1931) Inglis \& Cosgrove, 1965) Host: Lagothrix cana (É. Geoffroy, 1812) (Primates, Atelidae), Gray Woolly Monkey.

Locality: Brazilian Amazon, undetermined locality. Site of infection: large intestine.

Table 1. Morphometric data of Trypanoxyuris (Paraoxyuronema) lagothricis found in Lagothrix cana from Brazil and measures reported by other authors. Measures of $T$. (P.) brachytelesi previously recorded in Brazil are given for comparison. *Animal which came from South America and died in zoo. $\mathrm{L}=$ length, $\mathrm{W}=$ width, $\mathrm{D}$ = distance, $\mathrm{NA}=$ not available. Measures are given in micrometers, except for the length of the body which is given in millimeters.

\begin{tabular}{|c|c|c|c|c|c|c|c|}
\hline & & \multicolumn{5}{|c|}{ Trypanoxyuris (P.) lagotbricis } & \multirow{3}{*}{$\begin{array}{c}\text { T. (P.) brachytelesi } \\
\text { Artigas (1936) } \\
\text { Female } \\
(\mathrm{n}=1)\end{array}$} \\
\hline \multirow{2}{*}{ Parameters } & & \multicolumn{2}{|c|}{ Present study } & \multicolumn{2}{|c|}{ Buckley (1931) } & \multirow{2}{*}{$\begin{array}{c}\text { Hugot }(1985) \\
\text { Females } \\
(\mathrm{n}=11)\end{array}$} & \\
\hline & & $\begin{array}{c}\text { Males } \\
(\mathbf{n}=10)\end{array}$ & $\begin{array}{l}\text { Females } \\
(\mathbf{n}=10)\end{array}$ & $\begin{array}{c}\text { Males } \\
(\mathbf{n}=\mathrm{NA})\end{array}$ & $\begin{array}{l}\text { Females } \\
(\mathrm{n}=\mathrm{NA})\end{array}$ & & \\
\hline \multirow{2}{*}{ Body } & $\mathrm{L}$ & $1.3 \pm 0.1(1.2-1.4)$ & $4.3 \pm 0.2(4.0-4.7)$ & 1.56 & $5-6$ & 4.1 & 9.5 \\
\hline & W & $72 \pm 3(69-79)$ & $309 \pm 23(264-340)$ & 80 & 300 & 250 & 608 \\
\hline Esophagus & $\mathrm{L}$ & $290 \pm 29(241-338)$ & $747 \pm 51(675-837)$ & 350 & 730 & 700 & 756 \\
\hline \multirow{2}{*}{ Esophageal bulb } & $\mathrm{L}$ & $59 \pm 3(54-65)$ & $120 \pm 5(112-131)$ & 60 & $104-112$ & 110 & 126 \\
\hline & W & $49 \pm 3(43-53)$ & $114 \pm 6(102-124)$ & 40 & $80-88$ & - & - \\
\hline $\begin{array}{l}\text { Nerve ring to } \\
\text { anterior extremity }\end{array}$ & $\mathrm{D}$ & $88 \pm 6(82-96)$ & $170 \pm 12(150-198)$ & - & 169 & 140 & - \\
\hline $\begin{array}{l}\text { Vulva to } \\
\text { anterior extremity }\end{array}$ & $\mathrm{D}$ & - & $1,079 \pm 91(956-1,222)$ & - & $\begin{array}{c}1,390- \\
1,676\end{array}$ & 1,150 & 1,976 \\
\hline Spicule & $\mathrm{L}$ & $43 \pm 2(40-46)$ & - & 44 & - & - & - \\
\hline Terminal spine & $\mathrm{L}$ & $17 \pm 2(15-20)$ & - & 15 & - & - & - \\
\hline \multirow{2}{*}{ Eggs } & $\mathrm{L}$ & - & $40 \pm 2(37-43)$ & - & $38-40$ & 35 & $48-51$ \\
\hline & W & - & $21 \pm 1(19-23)$ & - & 22 & 17 & $24-27$ \\
\hline Tail & $\mathrm{L}$ & - & $1,137 \pm 157(827-1,393)$ & - & - & 960 & 2,434 \\
\hline Locality & & \multicolumn{2}{|c|}{ Brazil } & \multicolumn{2}{|c|}{ England* } & England* & Brazil \\
\hline Host & & \multicolumn{2}{|c|}{ Lagothrix cana } & \multicolumn{2}{|c|}{ Lagothrix lagotricha } & Lagothrix sp. & Brachyteles arachnoides \\
\hline
\end{tabular}



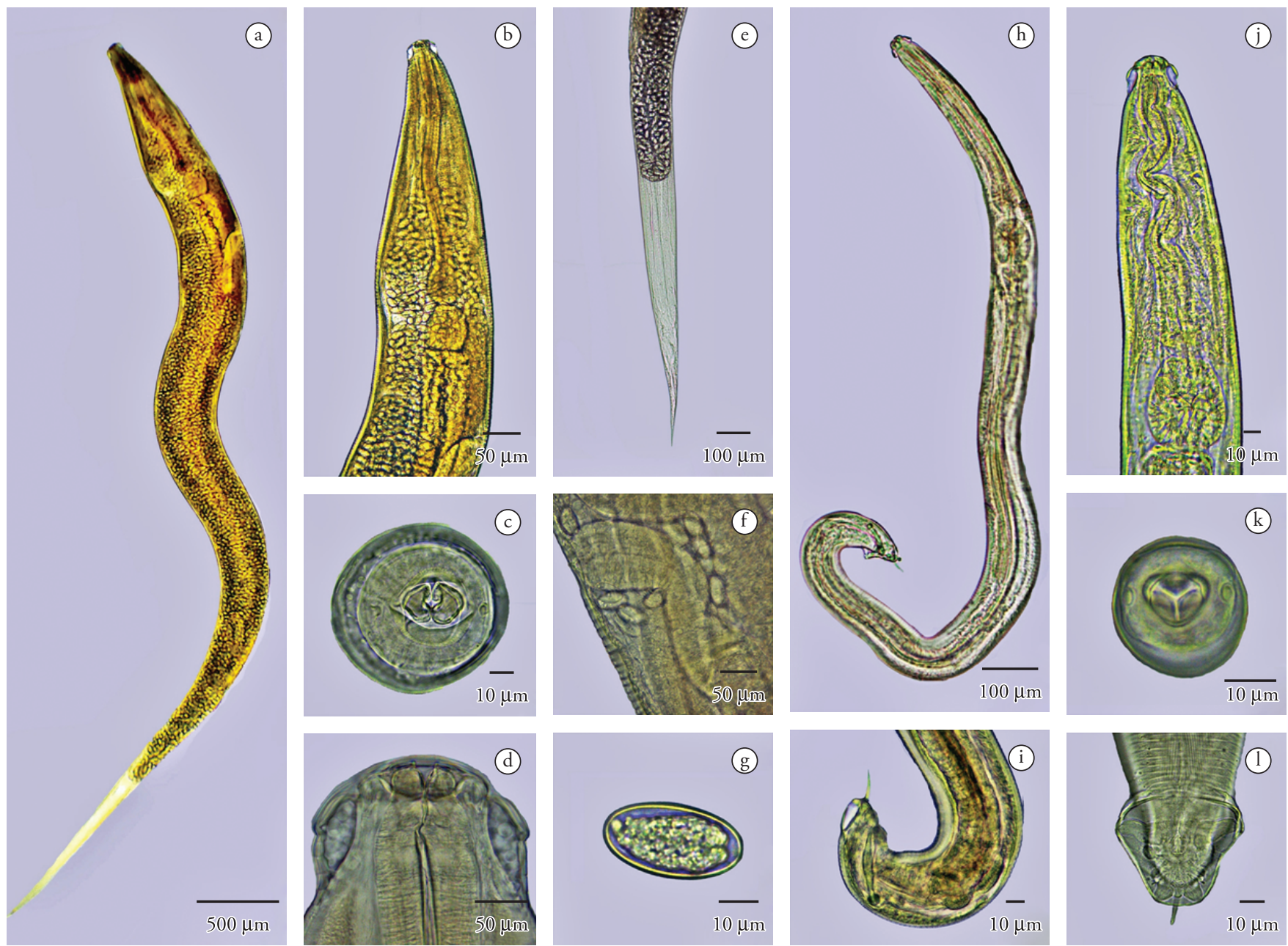

Figure 1. Trypanoxyuris (Paraoxyuronema) lagothricis found in Lagothrix cana from Brazil. (a-f) female: (a) total view, (b) anterior region, lateral view, (c) apical end, en face view, (d) anterior region, detail of extremity, ventral view, (e) tail, lateral view; (f) detail of ovejector, lateral view. (g) Egg found in the feces. (h-l) male: (h) total view, (i) posterior region, lateral view, (j) anterior region, ventral view, (k) apical end, en face view, (l) tail, ventral view.

Intensity of infection: 64 parasites (17 males, 47 females). Specimens deposited: DPIC 2467.

Remarks: Trypanoxyuris (Paraoxyuronema) lagothricis was described from a single infected specimen of Lagothrix lagotricha (Humboldt, 1812) (= Lagothrix humboldtii É. Geoffroy, 1812) originated from South America and taken to a London zoo (BUCKLEY, 1931). Later, the species was reported in L. lagotricha in Venezuela and Peru, and in L. cana, also in Peru (INGLIS; DÍAZ-UNGRIA, 1960; INGLIS; DUNN, 1964; HUGOT, 1985; TANTALEAN et al., 1990). This is the first report on the occurrence of this parasite in Brazil. The measures (Table 1) and morphological features of the specimens studied, as well as the structural arrangement of the buccal cavity, the presence of ventral esophageal teeth with a small apical end, and the shape of male bursa and female ovejector are in agreement with those reported for T. (P.) lagothricis by Buckley (1931) and Hugot (1985). In relation to other species of Trypanoxyuris reported in Brazilian primates, $T$. (P.) lagothricis differs from the species belonging to subgenera Hapaloxyuris and Trypanoxyuris by presenting two lips instead of three. Moreover, T. (P.) lagothricis presents measures of both males and females significantly smaller than the five other species from other subgenera previously reported in Brazil. In relation to T. (P.) brachytelesi, a species described based only on female parasites and with buccal structure not studied, T. (P.) lagothricis presents structures also significantly smaller. Regarding other species of the subgenus Paraoxyuronema not yet reported in Brazil, T. (P.) lagothricis can be easily distinguished from $T$. (P.) duplicidens which presents several larger measures, mainly the length of esophagus, teeth subdivided by a deep groove, and lacks a terminal spine in the male; the species reported in the present study also differ from $T$. (P.) atelis in which presents greater total length, and ventral esophageal teeth with a verrucose ornamentation instead a small apical point (HUGOT, 1985).

The clinical manifestations verified in the infection with Trypanoxyuris as well as other pinworm infections are not significant in most cases. Anal itching and irritation, irritability, agitation, and aggressiveness of the host are the clinical signs usually verified during the course of the disease (TOFT II, 1982). However, the occurrence of high parasitic burden and erratic parasitism has been observed and, in some cases, it may be associated with the 
death of the host (MURATA et al., 2002; AMATO et al., 2002; FOX et al., 2002). In the present study, there was no evidence that infection with $T$. (P.) lagothricis was associated with the death of the specimen studied. In fact, during the necropsy of the primate, there were no gross changes such as edema, hyperemia, or mucosal lesions of the caecum, colon and rectum of the animal, at least in part, due to low intensity of infection.

Considering the biology of these oxyurids, conditions of captivity and close contact between primates may favor the transmission and maintenance of the parasite (FELT; WHITE, 2005; BARROS MONTEIRO et al., 2009). Indeed, T. (P.) lagothricis was first described and found in animals from zoos (BUCKLEY, 1931; HUGOT, 1985). Similarly, the specimen of L. cana studied was kept for an unknown period of time under illegal captivity before being confiscated.

Under an evolutionary approach, studies of primate oxyurids have provided evidence of the process of coevolution between these parasites and their hosts. Cameron (1929) was the first to find high host specificity in this group of nematodes, suggesting that each species of these parasites would occur in specific groups of primates. Evidence for this phenomenon was subsequently obtained for genera belonging to the subfamily Enterobiinae, including Trypanoxyuris (BROOKS; GLEN, 1982; HUGOT et al., 1996; HUGOT, 1998, 1999).

Given the close evolutionary relationship between Trypanoxyuris and their platyrrhine hosts, as well as reports of infection of these primates in other South American countries with species not yet recorded in Brazil, it is possible that the diversity of these oxyurids occurring in the country could be underestimated. In this regard, at least nine other species of Trypanoxyuris, which have already been reported in South American primates, may still be found in Brazil: T. (T.) trypanuris Vevers, 1923 in Pithecia spp. (Primates: Pitheciidae); T. (H.) goldii (Inglis \& Coosgrove, 1965) in Callimico spp. (Primates: Cebidae); T. (H.) tamarini (Inglis \& Dunn, 1964) and T. (H.) oedipi in Saguinus spp. (Primates: Cebidae); T. (P.) atelis (Cameron, 1929) in Ateles spp. (Primates: Atelidae); T. (P.) duplicidens (Buckley, 1931) in Lagothrix spp.; T. (T.) satanas Hugot, 1985 in Chiropotes spp. (Primates: Pitheciidae); T. (T.) croizati Hugot, Morand \& Guerrero, 1994 and T. (T.) callicebi Hugot \& Vaucher, 1985 in Callicebus spp. (Primates: Cebidae). Moreover, primates belonging to the genera Leontopithecus Lesson, 1840, Cebuella Gray, 1866 (Primates: Cebidae) and Cacajao Lesson, 1840 (Primates: Pitheciidae) have not yet been reported infected with Trypanoxyuris (HUGOT, 1999), and they may be hosts of unknown species.

Overall, the study of helminth parasites from primates in Brazil is fragmented. Although the Brazilian primate fauna currently comprises 118 species (PAGLIA et al., 2012), most primate species have not yet been evaluated for infection by parasites. So far, only 27 species of nematodes have been reported in 36 species of primates in the country, and only four nematodes species in primates of the genus Lagothrix (revised by VICENTE et al., 1997; PINTO et al., 2011). On the other hand, the reduction of natural habitats and illegal hunting have contributed to a substantial number of endangered primate species (26) in Brazil (CHIARELLO et al., 2008). In fact, the reduction of populations, and even extinction of hosts, can also be related to the co-extinction of parasite species (WHITEMAN; PARKER, 2005; DOBSON et al., 2008; MUNIZ-PEREIRA et al., 2009). Thus, it is possible that other species of Trypanoxyuris and several other parasitic interactions be eliminated before they become known. In this way, conservation of primate species is important for the maintenance of these parasite species. Furthermore, the scientific interaction between primatologists and helminthologists should be encouraged to maximize achievement on parasitological information, thereby contributing to increase the knowledge on the biodiversity of helminths from primates in Brazil.

\section{References}

Amato JFR, Amato SB, Calegaro-Marques C, Bicca-Marques JC. Trypanoxyuris (Trypanoxyuris) minutus associated with the dead of a wild southern brown howler monkey, Alouatta guariba clamitans, in Rio Grande do Sul, Brazil. Arq Inst Biol 2002; 69(4): 99-102.

Anderson RC. Méthode pour l'examen des nématodes en vue apicale. Ann Par Hum Comp 1958; 33(1-2): 171-172.

Artigas PT. Estudios helminthologicos. I. Paraoxyuronema brachytelesi g. n., sp. n., parasita de Brachyteles arachnoides (Geoff., 1806); Oxyuronemidae, fam. n. Mem Inst Butantan 1936; 10: 77-85.

Barros Monteiro FO, Coutinho LN, Araújo KF, Barros Monteiro MV, Castro PHG, Silva KSM, et al. Biochemical and haematological parameters in owl monkeys infected and uninfected with Trypanoxyuris sp. J Helminthol 2009; 83(3): 225-229. PMid:19638258. http://dx.doi. org/10.1017/S0022149X08156772

Brooks DR, Glen DR. Pinworms and primates: a case study in coevolution. Proc Helminthol Soc Wash 1982; 49(1): 76-85.

Buckley JC. On two new species of Enterobius from the monkey Lagothrix humboldtii. J Helminthol 1931; 9(3): 133-140. http://dx.doi. org/10.1017/S0022149X00030364

Cameron TW. The species of Enterobius Leach, in Primates. J Helminthol 1929; 7(3): 161-182. http://dx.doi.org/10.1017/ S0022149X00018770

Chiarello AG, Aguiar LMS, Cerqueira R, Melo FR, Rodrigues FHG, Silva VM. Mamíferos ameaçados de extinção no Brasil. In: Machado ABM, Drummont GM, Paglia AP. Livro Vermelho da Fauna Brasileira Ameaçada de Extinção. Brasília: Ministério do Meio Ambiente, 2008. p. 681-702.

Dobson A, Lafferty KD, Kuris AM, Hechinger RF, Jetz W. Homage to Linnaeus: how many parasites? How many hosts? Proc Natl Acad Sci USA 2008; 105(S1): 11482-11489. PMid:18695218 PMCid:2556407. http://dx.doi.org/10.1073/pnas.0803232105

Felt SA, White CE. Evaluation of a timed and repeated perianal tape test for the detection of pinworms (Trypanoxyuris microon) in owl monkeys (Aotus nancymae). J Med Primatol 2005; 34(4): 209-214. PMid:16053499. http://dx.doi.org/10.1111/j.1600-0684.2005.00111.x

Fox J, Anderson L, Loew F, Quimby F. Laboratory Animal Medicine. San Diego: Academic Press; 2002.

Hugot JP. Phylogeny of Neotropical monkeys: the interplay of morphological, molecular, and parasitological data. Mol Phylogenet Evol 1998; 9(3): 408-413. PMid:9667989. http://dx.doi.org/10.1006/ mpev.1998.0497 
Hugot JP. Primates and their pinworm parasites: the Cameron hypothesis revisited. Syst Biol 1999; 48(3): 523-546. PMid:12066292. http://dx.doi. org/10.1080/106351599260120

Hugot JP. Sur le genre Trypanoxyuris (Oxyuridae, Nematoda) II. Sousgenre Hapaloxyuris parasite de primates Callitrichidae. Bull Mus Natl Hist Nat Sect A: Zool 1984; 6(4): 1007-1019.

Hugot JP. Sur le genre Trypanoxyuris (Oxyuridae, Nematoda) III. Sousgenre Trypanoxyuris parasite de primates Cebidae et Atelidae. Bull Mus Natl Hist Nat Sect A: Zool 1985; 7(1): 131-155.

Hugot JP, Gardner L, Morand S. The Enterobiinae subfam. nov. (Nematoda, Oxyurida) pinworm parasites of primates and rodents. Int J Parasitol 1996; 26(2): 147-159. http://dx.doi.org/10.1016/00207519(95)00108-5

Inglis WG, Díaz-Ungria C. Nematodes parasitos de vertebrados venezolanos. I. Una revisión del género Trypanoxyuris (Ascaridata: Oxyuridae). Mem Soc Cienc Nat La Salle 1960; 19: 176-212.

Inglis WG, Dunn FL. Some oxyurids (Nematoda) from neotropical primates. Z Parasitenkd 1964; 24(1): 83-87. http://dx.doi.org/10.1007/ BF00260426

Martins SS, Ferrari SF, Silva CS. Gastro-intestinal parasites of free-ranging red-handed howlers (Alouatta belzebul) in Eastern Amazonia. In: Ferrari SF, Rímoli, J. A Primatologia no Brasil-9. Aracajú: Sociedade Brasileira de Primatologia; 2008. p. 114-124. PMid:18262012.

Muniz-Pereira LC, Vieira FM, Luque JL. Checklist of helminth parasites of threatened vertebrate species from Brazil. Zootaxa 2009; 2123: 1-45.

Murata K, Hasegawa H, Nakano T, Noda A, Yanai T. Fatal infection with human pinworm, Enterobius vermicularis, in a captive chimpanzee. J Med Primatol 2002; 31(2): 104-108. PMid:12110054. http://dx.doi. org/10.1034/j.1600-0684.2002.01017.x

Paglia AP, Fonseca GAB, Rylands AB, Herrmann G, Aguiar LMS, Chiarello AG, et al. Occasional Papers in Conservation Biology: Lista Anotada dos Mamíferos do Brasil. 2. ed. Arlington: Conservation International; 2012.
Pinto RM, Knoff M, Gomes DC, Noronha D. Nematodes from mammals in Brazil: an updating. Neotrop Helminthol 2011; 5(2): 139-183.

Souza DP, Magalhães CMFR, Vieira FM, Souza Lima S. Ocorrência de Trypanoxyuris (Trypanoxyuris) minutus (Schneider, 1866) (Nematoda, Oxyuridae) em Alouatta guariba clamitans Cabrera, 1940 (Primates, Atelidae) em Minas Gerais, Brasil. Rev Bras Parasitol Vet 2010; 19(2): 124-126. http://dx.doi.org/10.4322/rbpv.01902011

Souza Júnior JC, Goulart JAG, Varnier S, Denegri G, Silva Filho HH, Hirano ZMB, et al. Bertiellosis in Brazilian non-human primates: natural infection in Alouatta guariba clamitans (Cabrera, 1940) (Primates: Atelidae) in Santa Catarina State, Brazil. Rev Patol Trop 2008; 37(1): 48-56.

Tantalean M, Gozalo A, Montoya E. Notes on some helminth parasites from Peruvian monkeys. Lab Primate Newsl 1990; 29(2): 6-8.

Toft II JD. The pathoparasitology of the alimentary tract and pancreas of nonhuman primates: a review. Vet Pathol 1982; 19(S7): 44-92. http:// dx.doi.org/10.1177/030098588201907s06

Travassos L. Revisão do gênero Enterobius Leach, 1852. Fauna brasiliense, Museu Nacional do Rio de Janeiro, 1925; 2: 1-11.

Valença MM, Oliveira JB, Cruz MAOM, Cavalcanti MD, Sá MEP. Trypanoxyuris (Hapaloxyuris) callithricis (Oxyurida, Oxyuridae) in wild Callithrix jacchus (Linnaeus, 1758), in Northeast Brazil. Lab Primate Newsl 2000; 39(2): 4-5.

Vicente JJ, Pinto RM, Faria Z. Spirura delicata sp. n. (Spiruridae, Spirurinae) from Leontocebus mystax (Callithrichidae) and a check list of other nematodes of some Brazilian primates. Mem Inst Oswaldo Cruz, 1992; 87(S1): 305-308. http://dx.doi.org/10.1590/S007402761992000500057

Vicente JJ, Rodrigues HO, Gomes DC, Pinto RM. Nematóides do Brasil. Parte V. Nematóides de mamíferos. Rev Bras Zool 1997; 14(S1): 1-452.

Whiteman NK, Parker PG. Using parasites to infer host population history: a new rationale for parasite conservation. Anim Conserv 2005; 8(2): 175-181. http://dx.doi.org/10.1017/ S1367943005001915 